\title{
THE IMPACT OF MULTISENSORY METHOD ON STUDENTS' MEMORIZING VOCABULARY AT HALIMAH KINDERGARTEN PRENDUAN SUMENEP
}

\author{
Nailan Al Adzillina ${ }^{1}$ \\ ${ }^{1}$ English Teaching Learning Program, Tarbiyah Faculty, Islamic Institute of Madura \\ (nailanaladazillina@gmail.com) \\ Henny Uswatun Hasanah ${ }^{2}$ \\ ${ }^{2}$ English Teaching Learning Program, Tarbiyah Faculty, Islamic Institute of Madura \\ (henny_doank83@yahoo.co.id)
}

\begin{abstract}
Young learners were aged 5-6 have a golden age to master a new language since they have good memorization in their brains. It is similar to the phenomenon at Halimah Kindergarten Prenduan Sumenep. 11 students had mastered their first language (Indonesian) 8 of 11 students among them cannot answer the teacher's question about English vocabulary of profession after the teacher taught learning vocabulary in the classroom. Additionally, the students are still difficult to answer the questions. Ultimately, this research measures whether kindergartens students learning vocabulary with the Multisensory Method have better-memorizing vocabulary and the significant impact of the Multisensory Method after treatment. The researcher conducted research using a quantitative approach with consist pre-experimental design. The data was obtained by observing pre-test and post-test. Likewise, documentation was used to legitimize the data. The data result found that learning vocabulary for the young learner is easier to understand if the teacher applies a multisensory method ( $t$ value: 5.164) which is higher than t table 2.23. Hence, the multisensory method is an excellent method to be applied for kindergarten in the classroom.
\end{abstract}

Keywords: Multisensory Method; Very Young Learners; Vocabulary

First Received:

(March 12, 2021)
Final Proof Received:

(September 30, 2021)

\section{INTRODUCTION}

Generally, vocabulary is the knowledge of the meanings of words (Hiebert \& Kamil, 2005). It means that vocabulary is the basic knowledge to express someone's ideas in writing or speaking skills. Without vocabulary, someone has difficulties expressing language. Due to these reasons, vocabulary must be learned for students who desire to have good communication. For sure, every language has a similar phonetic symbol, its transcriptions. This symbol is called vocabulary. Vocabulary is part of language's elements besides grammar and pronunciation.

In school, children have a big chance to express their language environment around them, written or spoken expression. Generally, children prefer to use their ideas in spoken language. Since they are getting interaction with their friends, or the teachers, to express children's ideas, they need vocabulary as a media expression. It is a big opportunity to develop student's language skills if the teacher gives many new vocabularies to the 
children. To be memorized by children. Children in kindergarten school divide into two age part class. First, the children who consist age 4-5, is the young learner in A-class. Second, the children who consist age 5-7, is the young learner in B class. The students in 57 years old should have the better-memorizing vocabulary to develop their language speaking or writing skills.

In this case, students who become language learners must learn vocabulary before they can rearrange words grammatically and pronounce them. According to (Suyanto, 2007), young learner is a kid who learns English after they learn their first language. There is a category that is called by a Very Young Learners. Young learners have highly a chance to learn their first language. The first language depends on the parents who Educate and motor actives them as a first School of a child. Rabbianty (2013) said young learners in age 5-7 Years old can understand the situation more quickly than they understand the language used.

The phenomenon is that students have a problem in memorizing English vocabulary, as long as the teacher teaches them in a traditional way such as reading vocabulary in the textbook. The researcher assumed that the teacher teaches students used the traditional method is less effective. It shows that the students cannot identify all of the vocabulary that the teacher has already explained. Such as what has been observed in Halimah Kindergarten. It is noticed that between 8/10 students were inactive in responding to English vocabulary that the teacher gives. In alternative ways, the researcher provides a solution to applying the multisensory method, suitable for kindergarten students. By this kind of method, the students will be instructed to act four senses such as seeing, hearing, touching, and moving in the learning process.

The researcher desires to conduct a Multisensory method in taught vocabulary. The initial activity focuses on students learning single Letters and blending letters to become a word. Students learn a single letter and its sound by using a tracing technique through the use of colors and images. The single sounds are combined into a larger group and short words (Utami, 2015). The use of multisensory methods involving various sensory modalities that it applies in teaching English vocabulary in the classroom. In addition, practice is implemented using sensory modalities such as Visual, Auditory, Kinesthetic, and Tactile (VAKT) principles by utilizing aids as a learning medium representing the function of each of the sensory modalities used so that it is expected to be able to assist in the learning process.

Using a multisensory teaching method means helping students to learn vocabulary through more than one sense. Most teaching techniques are done using either sight or hearing (Auditory or Visual). The students might use to read the information, look at a text, picture, or read on the whiteboard. The hearing sense is used to listen to anything that teacher says. Sometimes student's auditory processing may be weak. The solution for this problem is to involve the use of more students' senses, Especially the use of touching 
(tactile) and moving (kinesthetic). Using the multisensory method will help students' brains develop tactile and kinetic memories to hang on to and the auditory and visual ones (Praveen, 2010).

Thus, kindergarten Children have sensitivity in Remembering something or information. Identical characters who imitate and practice themselves in everyday life indicate that they are a good reminder. However, they don't necessarily understand what they are copying. An excellent ability to remember automatically will add to the new vocabulary of students. Therefore, the researcher desires to focus on students' memorizing vocabulary because the problem results from students memorizing.

Some studies have been conducted about the impact of multisensory methods in teaching-learning students. (Maliki \& Yasin, 2017) study, for example, used to determine the level of progress in learning alphabets identification skills after applying the multisensory method in special education learning for children with learning disabilities. This study is conducted using a quasi-experimental approach upon six students with learning disabilities selected by way of purposive sampling. The students are divided into two groups. The results indicated that the multisensory method is effective and appropriate to be applied concerning children with special needs due to their learning disabilities in terms of alphabets identification.

Moreover, (Obaid, 2013) studies about the multisensory method have also been conducted in the last four years about the effect of using the Multi-Sensory Approach for teaching students with learning disabilities on the sixth-grade students' achievement in mathematics at Jordanian public schools. The study's findings indicated that there were statistically significant differences in the post-test between the control and the experimental groups in favor of the experimental group. The researcher proposed some recommendations to enhance the importance of parental involvement on students' achievement in the English language, such as conducting further studies on other populations and for a longer time.

Furthermore, (Tutupoly, Siswati, \& Widodo, 2013) and carry out a study to discover the effectiveness of the multisensory method to increase memorizing ability of English vocabulary compared to increasing students' elementary reading skills. The authors found that both formats' multisensory method effectively increases the memorizing ability of English vocabulary. It shows improving students' ability in memorizing words. Regarding the lack of research within the area, they stated that "There are increasing students ability identifying words accurately. Even though, it is not significant".

As discussed, several studies have been conducted relating multisensory methods in various learning. To the best of our knowledge, few studies have been done on students with disabilities or abilities in learning using multisensory methods. Hoping to fill this gap, the present study investigates the impact of the multisensory method on memorizing English vocabulary for kindergarten students who do not have disability. Hence, this paper 
aims to see whether teaching English vocabulary by using multisensory method has any significant effect on improving kindergarten students' memorizing English vocabulary. Based on this that the following research question and hypothesis were proposed for the study:

Question: Does the multisensory method have any significant impact on kindergarten students' memorizing English vocabulary?

Hypothesis: Multisensory Method does not have any significant impact on kindergarten students' in memorizing English vocabulary.

\section{LITERATURE REVIEW}

\section{Multisensory}

The multisensory learning approach is a term many schools use to describe teaching methods that involve engaging more than one sense simultaneously (Hoye, 2018). Involving the use of visual, auditory, tactile, and kinesthetic pathways, the students can experience a lesson through multiple pathways. It can be best brain's stimulate and engage students deeply to understand the subject matter.

The multisensory method conducted by Orton Gillingham is the most suitable effective learning for Kindergarten students. The students who have a problem in memorizing vocabulary. Correlated with students' learning styles, the multisensory method could be an alternative way to teach English vocabulary. They inactivated four sensories when the classroom activity began. The students allow choosing their learning styles.

\section{The Principle of Multisensory Method}

Multiple studies, including those from the National Development, showed that a multisensory method is the most effective teaching method for children who have difficulties in learning (Hoye, 2018). This belief is that students learn a new best concept when it is taught four modalities. Based on the theory above, multisensory actives four sensory modalities; of course, this relates to student's learning styles. The scientist found that the students who study using their learning styles dominantly, it will have a better result. For example, when the students face a test, they will have better scores by using their learning styles than those who don't (Gunawan, 2006).

The principles of Multisensory submitted by Orton G (Ahearn, 2016);

1. Visual Learning. Learners need to be able to recall what has been presented visually, such as the appropriate letters patterns to match sounds to be able to spell and recognize letters in combination for reading. The observation of picture diagrams can support students' understanding.

2. Auditory Learning. It relates to students' auditory memory. This memory to listen, process, store, and recall all things. Aside from the obvious requirement to be able to follow instructions and to remember information verbally. 
3. Kinesthetic Learning. Kinesthetic learning is a type of active learning in which students participate to act out what students' learning.

4. Tactile Learning. This learning is ideal with tactile cognition. The study of the information flow and analysis of a sequence of events occur in students' minds while receiving a new piece of bodily tactile information. The information processing starts very early by seeking out, focusing, and selecting particular aspects of the available information.

\section{The Techniques and Procedures of Multisensory Method}

Multisensory techniques and strategies stimulate learning by engaging students on multiple levels. The students use some sense to store information and store it for later recall. Using a multisensory teaching technique means helping students to learn through more than one sense. Most teaching techniques are done using either sight or hearing. The teaching procedures by Orton G. method are as follow;

1. Showing a letter card to the students concerned.

2. Without showing a letter card, the teacher says the sound and asks the letter's sound just told by the teacher before.

3. The teacher writes the letter on a whiteboard.

4. After mastering few letters, the students begin to be taught to rearrange letters into a word.

\section{Testing English Vocabulary}

Vocabulary is all the words that a person knows or uses or lists of words with their meaning, especially in a book for learning a foreign language (Oxford Dictionary, 2008). Horn defined vocabulary as the total number of words in a language; that has meanings (Alqahtani, 2015). Based on the definitions above, the researcher concludes that a vocabulary is several words that are needed to communicate and express someone's ideas through speaking and writing. Thus the basic reason the students must have several vocabularies.

There are kinds of vocabulary that should know by a teacher. Harmer distinguishes between these two types of vocabulary. The first type refers to the students who have been taught and are expected to be able to use it daily. Meanwhile, the second type refers to the words that students should recognize but probably not be able to pronounce.

There are two kinds of vocabulary. Receptive vocabulary is words learners recognize and understand in the context, but they cannot produce it. Besides Productive vocabulary is the words that learners understand, pronounce correctly, use constructively in speaking and writing. For very young learners that in age 5 to 7 , the students include Productive vocabulary learners. At age 5 to 6 years old, children already rearranged structure and grammar sentences using prefixes and verbs. The average sentence length is half a sentence 
per line which increases by 6 to 8 words. In this age range, the children have to be able to use a vocabulary of about 2500 words and can understand about 6000 words.

The purpose of the vocabulary test is to measure the comprehension and production of the five words used. The tests are presented by Madsen (Hamida, 2016); a. Limited response, b. Multiple choice completion, c. Multiple choice paraphrase, d. Simple completion. Testing Young learners usually use simple completion such as gap filling, missing words, and guess the picture.

\section{The Elements of Memorizing}

Literary, the word memorizing is memory. Memorizing is an activity that acts in memory. The process of memorizing means how the words or information come and save in memory. According to (Soemanto, 2006), remembering absorbed or embed knowledge by active denial. While the properties of good memory are loyal, fast, received in a long time, wide, and ready (Pratiwi, 2017). Another scientist (Bhinnety, 2015) divided three places of the memory system;

1. A sensory-term memory system is recording information and stimulating through one or a combination of five senses.

2. A short-term memory system is a grouping of items into several chunks and giving codes to information.

3. A long-term memory system stimulates after the information is saved in such a long time in short memory, and then the information transfers again by repetition to the long-term memory system to be stored. If the information was lost or forgotten, it was replaced by adding new pieces of information.

According to (Baharuddin, 2008) remembering allows individuals to still have impressions after the experience. Therefore, memorizing activities must fulfill the following elements (Pratiwi, 2017).

1. Thinking material structure of impressions kept in mind is clear. Mind subject need concentrating those impressions. The material should be arranged systematically. So that it is easy to understand.

2. Retaining. Retaining information that has been stored will save the in-memory system.

3. Producing. After recalling information in the brain, then the information carries out to produce in the production process.

Memorizing is not easy to do. Moreover, these are the young learner difficulties in memorizing English vocabulary, such as;

1. Pronunciation. Every language automatically has its pronunciation. English also has a different pronunciation. Different phonetic transcription of each vocabulary makes students difficult to memorize because writing and speaking have different sounds. Example know-now, egg-eight, wood, would, were-where, and so forth. 
2. Ambiguity. English vocabulary has many similarities on a lexical relationship such as same in the written and pronunciation but different meaning, example; water means drinking or probably for watering a plant.

\section{Very Young Learner}

A young learner is a kid who learns their first language. There is a category that the very young learners call. very young learner or pre-schooling is a child were studies at kindergarten school. (Suyanto, 2007). The other words, children are not adults (Rabbianty, 2013). Young learners are still learning about the world, between learning a sense of space and time. The young learner becomes capable of abstract thought. All children achieve these stages, but at different ages.

The different characteristics of young learners caused different personalities and also language development. Based on a book that Eva wrote stated that the age level of young learners is divided into two levels, the first is 5 to 7 years old and the second is 8 to 11 years old. Thus ages can talk about what they are doing, what they have done or heard, and they can plan an activity.

Classroom management is a process of ensuring classroom lessons run smoothly despite disruptive behavior by students (Zhou \& Brown, 2015). Teaching English for very young learners must have some classroom management strategies to make them enjoy the class activities such as; circle ( $\mathrm{O}$-shape) of seating each student, and the teacher remember the student's names.

On the other hand, after the teacher prepares material, method, and student's seats position. The teacher must prepare media. The media will apply to the teaching-learning process. This media will support children's understanding and succeeding a method. There are media in teaching very young learners; alphabet shape, flashcard, whiteboard, mannequin, and other visual media.

\section{METHOD}

In this research, the researcher used the pre-experimental method on quantitative approach with a one-group pretest-posttest design. It aims to measure two variables after and before treatments. This design is described as follow:

Note :

$$
\mathrm{O}_{1} \mathrm{X} \mathrm{O}_{2}
$$

$\mathrm{O}_{1}=$ The score of pre-test (before given a treatment)

$\mathrm{X}=$ Treatment

$\mathrm{O}_{2}=$ The score of a post-test (after being given a treatment) 


\section{Instruments}

In gathering the data, the researcher used two instruments, namely pre-test-Posttest and documentation. The test was used to measure the impact of a multisensory method to know who was a student has better memorizing English vocabulary. The test included filling the black or gap-filling in guessing pictures. The researcher gave a test to students consists ten questions. The students should do it for 15 minutes for each part. Then, the researcher collected the data from the students' name list, daily worksheet, a score of memorizing vocabulary test, a test and key answer of a test, and photos when carrying out the test.

The data was coming after the participant observation phenomenon in the classroom activities. This research data was taken from the young learners in fifth until sixth in B class at Kindergarten Halimah Prenduan Sumenep inside the classroom activities with the researcher as the teacher-active participant. The result of the tests and observation of the data were used to answer the problems of the study.

\section{Data Collection}

Data collection techniques were the efforts of researchers to collect data obtained in the place which the researcher takes. After the researcher asked permission to headmaster the researcher to collect the data, the researcher made pre-test and post-test duration on seven days each test that the teacher accepted. Before the post-test was taken, the researcher did the treatment on two days of multisensory method in teaching 10 kinds of a profession in English. The test was taken with the students at different times. It was caused by the researcher have to take the validity of the data. Thus, it all depends on students' condition in taking the data. The students consisted of 11 students at Halimah Kindergarten Prenduan Sumenep. According to (Arikunto, 2010), if the population was less than 100, the researcher took all of the students, and if the population was more than 100 , take $10-15 \%$ or $20-25 \%$ or more. Because the students of TK B Halimah were less than 100 , so the researcher took all of the students as a sample of this research.

\section{Data Analysis}

The researcher used statistical analysis. The statistical analysis is suitable with quantitative characteristics, namely numerical form. This study is analyzed based on the result of pre-test and post-test, the researcher used dependent T-Test. The data analysis procedures are proposed by (Anas, 2017) to count the data.

\section{RESULTS AND DISCUSSION}

\section{Results}

The findings of test and documentation data as a method to collect the data found a relationship between variable $\mathrm{X}$ (multisensory method) and variable $\mathrm{Y}$ (memorizing vocabulary). The researcher took all the years old that consist of 11 (eleven) students. The 
test was given to kinds of the test by researcher, pre-test, and post-test using instruments of the test. The form of the test is fill in the black or gab filling on guessing picture in scoring for answering the test, and the researcher gives ten scores for each item of the correct answer and 0 scores for the wrong answer which the researcher has provided. The test consists of 10 questions. If the students can answer all of the questions correctly, the score is 100 scores. After the students submitted the test to a researcher, then the researcher's score is based on the criteria of scoring which are taken from the teacher who made the test and Assessment Anak Usia Dini Book which was submitted by Didith P and other references. The result of the Pre-test is under bellow:

Table 1.

The result of pre-test

\begin{tabular}{lll}
\hline NO. & Initial of the correspondences & Pre-test Score \\
\hline 1 & L & 80 \\
\hline 2 & B & 20 \\
\hline 3 & A & 60 \\
\hline 4 & F & 0 \\
\hline 5 & F & 60 \\
\hline 6 & C & 30 \\
\hline 7 & R & 50 \\
\hline 8 & N & 40 \\
\hline 9 & A & 60 \\
\hline 10 & M & 30 \\
\hline 11 & I & 20 \\
\hline SUM & & 450 \\
\hline
\end{tabular}

It is found that the total pre-test score of students' memorizing vocabulary is 450 scores before giving treatment. From the table above, there are many various scores. Students who get a score above 60 are 4 students, it can be called a good memorizer, and students who get a score under 59 are 7 students, or it is called a weak memorizer.

After the researcher collecting the pre-test for the students for two days, the researcher conducted the post-test in testing memorizing vocabulary to collect the score after treatment in 7 days. The scores of post-test were presented in the table as follow: 
Table 2.

The result of post-test

\begin{tabular}{lll}
\hline NO. & Initial of the correspondences & Post-test Score \\
\hline 1 & L & 90 \\
\hline 2 & B & 90 \\
\hline 3 & A & 90 \\
\hline 4 & F & 70 \\
\hline 5 & F & 90 \\
\hline 6 & C & 70 \\
\hline 7 & R & 70 \\
\hline 8 & N & 80 \\
\hline 9 & A & 70 \\
\hline 10 & M & 50 \\
\hline 11 & I & 40 \\
\hline SUM & & 450 \\
\hline
\end{tabular}

From table 2 above, it is found that the total score of students' memorizing vocabulary is 810 scores after the teacher gave treatment. From the table above, there are many various scores. Students who get the score above 60 are 9 students, it can be called a good memorizer, and students who get score under 59 are 2 students or it is called a weak memorizer.

After the researcher counted the score of Pre-test and Post-test, the researcher compared the mean of pre-test and Post-test through data analysis. The research used a dependent t-test to analyze the data, which included two test instrument results, pre-test and post-test. Based on the calculation of the dependent t-test, the researcher finds $t_{O}=$ 5.164 , to know whether a null hypothesis is rejected or accepted, must be done process of hypothesis testing.

To consult to $t$-value on the level of significance $5 \%$. Obviously, in $\mathrm{df}=10$, the $\mathrm{t}$-value that can be obtained on t-table in the level significance $5 \%$ is 2.04 . After $t_{0}=5.164$, then, compare with $\mathrm{t}$-value on $\mathrm{t}$-table of 2.23. the researcher stated that a null hypothesis is rejected, and the alternative hypothesis( $\mathrm{Ha}$ ) is accepted because $t_{0}>t_{t}$ (5.164>2.23). Finally, the researcher infers that the alternative hypothesis is accepted. So, this research concludes that the multisensory method impacts students' memorizing vocabulary at TK B Kindergarten Prenduan Sumenep.

\section{Discussion}

Early recall ability possessed by the study subjects was measured using pre-test English recall ability. The pre-test is done before the treatment of the object under study. The results of this pre-test are then tested using the independent statistic t-test technique. The purpose of this test was to find out the difference in initial recall skills 
owned by the research object, namely students aged 5-6 years in kindergarten B group at Halimah Prenduan Kindergarten. The results of this analysis showed a significant difference in proficiency given English vocabulary between pre-test and post-test.

According to the results of comparison of the scores of students who experience increased proficiency recall, multisensory methods help children make it easier to learn English vocabulary. In addition to students who have a period of sensitivity to something, teaching teachers in transferring materials when understanding their students is also very influential in helping students learn. Montessori, as quoted by (Nurhayati, 2011) says that children who are 6-7 years old are in a language-sensitive period.

Children learn language more effectively due to neurological factors, where the condition is still plastic to reorganize if it encounters a new language system. In these sensitive times, teachers can teach much new vocabulary in English. In addition, it does not rule out the possibility that children also have difficulty in storing the information they just received. Before the researcher conducted the pre-test, the researcher observed how to teach the teacher in the classroom. The method that teachers do is still traditional, namely mentioning it through singing only then students follow. This method can be alternative way to teach the students, especially in vocabulary

The researcher, as the active participant, does treatment in teaching the students after the pre-test. The researcher used the multisensory method in teaching English vocabulary. The researcher gives ten vocabularies of the profession using a multisensory method with four modalities to the 11 students. The multisensory method utilizes more than two sensory modalities, enabling more than one storage part of the brain. The impact is the increase in information storage capacity (Willis, 2008). Therefore students can activate their 4 senses between visual, auditory, kinesthetic, and tactile. Those modalities were conducted by Orton G.

The National Institute of Child Health and Human Development showed that a multisensory method is the most effective teaching method for children who have difficulties in learning. The belief is that students learn a new concept best when it is taught using the four modalities. It means that students learn best when information is presented in different modalities, so that the students can choose their learning styles. Consequently (Celik Korkmaz \& Karatepe, 2018) revealed in his study that it can be inferred that learning through multisensory materials has not only made a long-lasting impact on the learning experience but also made learning more concrete and enjoyable; thus, it is more memorable. Furthermore, (Jubran, 2012) stated in his study that using a multisensory approach is a powerful tool with which students can learn English language with entertainment.

In addition, the multisensory method also utilizes tools that represent the function of each sensory modality, such as visual by writing, auditory with repetition pronunciation, kinesthetic by composing words using plastic letters, and tactile by writing 
it in the air. Some of these learning media are expected to help generate motivation, interest, and interest of students who will influence the concentration of children learning in remembering and understanding lessons to store well in their memory. The increasing concentration of students on the material will bring full attention to the material, making the subject matter easier to remember (Darling-Hammond, Flook, Cook-Harvey, Barron, \& Osher, 2020). Thereby, if the students who study using their learning styles dominantly, it will have a better result. For example, when the students face a test, the students will have better scores by using their learning styles than those who don't (Gunawan, 2006). Hence, Students showed more recall skills after researchers performed treatment through this multisensory method with better results.

\section{CONCLUSIONS}

This study examined the impact of the multisensory method on students' memorizing English vocabulary at Halimah Kindergarten Prenduan, Sumenep. It was found that the impact of the multisensory method by kindergarten students' age in 5-6 had a significant impact on the students' memorizing vocabulary. The students who learned English vocabulary used their learning styles, did significantly better on the post-test. Based on the findings of this study, applying various modalities in learning English vocabulary made students' easier to learn and understand the material because they learn it by their learning styles such as auditory, visual, kinesthetic, or tactile ways. Hence, the teacher must provide alternative teaching methods for improving English elements through memorizing activities in various modalities. Every kindergarten student' had unique, different learning styles. For this reason, the teacher should be known students' learning styles to be appropriated methodology on the role of the effective teachinglearning process.

\section{REFERENCES}

Ahearn, M. (2016, December 12). The OG Approach | Academy of Orton-Gillingham Practitioners and Educators. Retrieved September 27, 2021, from https://www.ortonacademy.org/resources/og-approach-principles/

Alqahtani, M. (2015). The Importance of Vocabulary in Language Learning and How to be Taught. International Journal of Teaching and Education, 4(3), 21-34.

Arikunto, S. (2010). Prosedur Penelitian: Suatu Pendekatan Praktik. Jakarta: Rineka Cipta.

Baharuddin. (2008). Psikologi Pendidikan. Solo: Tiga Serangkai.

Bhinnety, M. (2015). Struktur dan Proses Memori. Buletin Psikologi, 16(2), 74-88. doi: $10.22146 /$ bpsi.7375

Celik Korkmaz, S., \& Karatepe, C. (2018). The Impact of Multi-Sensory Language Teaching on Young English Learners' Achievement in Reading Skills. Novitas-ROYAL (Research on Youth and Language), 12(2), 80-95. 
Darling-Hammond, L., Flook, L., Cook-Harvey, C., Barron, B., \& Osher, D. (2020). Implications for Educational Practice of the Science of Learning and Development. Applied Developmental Science, 24(2), 97-140. doi: 10.1080/10888691.2018.1537791

Gunawan, Adi. W. (2006). Genius Learning Strategy Petunjuk Praktis untuk Menerapkan Accelarated Learning. Jakarta: Gramedia.

Hamida, A. (2016). The Effectiveness of Personal Vocabulary Notes (PVN) Technique in Improving Students' Vocabulary Achievement in the First Grade Students at SMP Islam al-Azhaar (Thesis). IAIN Tulungagung.

Hiebert, E. H., \& Kamil, M. L. (2005). Teaching and Learning Vocabulary: Bringing Research to Practice. London: Routledge.

Hoye, C. (2018, March 28). Benefits of the Multisensory Approach in the Classroom. Retrieved September 27, 2021, from The Gateway School website: https://thegatewayschool.com/multisensory-approach-special-education/

Jubran, S. (2012). Using Multisensory Approach for Teaching English Skills and Its Effect on Students' Achievement at Jordanian Schools. European Scientific Journal, ESJ, 8(22). doi: 10.19044/esj.2012.v8n22p\%p

Maliki, N., \& Yasin, M. (2017). Application of Multisensory in Learning Alphabets Identification Skills for Special Education Students. Journal of ICSAR, 1(2), 150-154. doi: $10.17977 /$ um005v1i22017p150

Nurhayati, E. (2011). Psikologi Pendidikan Inovatif. Yogyakarta: Pustaka Pelajar.

Obaid, M. A. S. (2013). The Impact Of Using Multi-Sensory Approach For Teaching Students with Learning Disabilities. Journal of International Education Research (JIER), 9(1), 75-82. doi: 10.19030/jier.v9i1.7502

Pratiwi, A. F. (2017). Peningkatan Daya Ingat Anak Usia Dini Melalui Media Mind Mapping pada Kelompok B di TK Islam al-Muttaqin Kota Jambi (Tesis). Universitas Jambi.

Praveen, A. V. (2010, August 6). What are Multisensory Instruction Techniques for Teachers and Parents? Retrieved September 27, 2021, from Learning Center for children who learn differently, their teachers and parents in Dubai, Middle East website: https://www.lexiconreadingcenter.org/what-is-multisensory-teachingtechniques/

Rabbianty, E. N. (2013). Teaching English to Young Learners. Surabaya: Salsabila Creative.

Soemanto, W. (2006). Psikologi Pendidikan. Jakarta: PT. Rineka Cipta.

Suyanto, K. K. E. (2007). English for Young learners. Jakarta: Bumi Aksara.

Tutupoly, J. F., Siswati, \& Widodo, P. B. (2013). Efektivitas Metode Multisensori Terhadap Kecakapan Mengingat Kosakata Bahasa Inggris pada Siswa Kelas 1 Sekolah Dasar (Studi Eksperimental di SD Negeri Tembalang Semarang). Jurnal Psikologi Universitas Diponegoro, 12(2), 100-108.

Utami, S. (2015). The Students' Ability in Using Derivational Suffixes. Jurnal Cemerlang, $3(1), 19-27$.

Willis, J. (2008). How Your Child Learns Best. Illinois: Sourcebooks Inc.

Zhou, M., \& Brown, D. (2015). Educational Learning Theories (2nd ed.). Georgia: Dalton Stage College. Retrieved from https://oer.galileo.usg.edu/education-textbooks/1 